\title{
Comparison the Serum Level of Prolactin Among Patients With Chronic and Episodic Migraine
}

\author{
Saberi Alia ${ }^{a}$, Roudbary Seyed Alia, ${ }^{\text {, Elyasi Nafieh }}{ }^{\mathrm{a}}$, Kazemnejad Ehsan ${ }^{\mathrm{a}}$
}

\begin{abstract}
Background: Increased serum prolactin level is suggested as one of factors for migraine to being chronic. The Aim of this study is comparison the serum level of prolactin among patients with chronic and episodic migraine.
\end{abstract}

Methods: This cross-sectional study was performed from 2011 July till 2012 November among 114 female migrainous. The subjects who involved by menstrual irregularity, anxiety, depression, hypo or hypothyroidism, anemia, polycythemia, epilepsy, and pregnant, lactating, prepuberty and postmenopause patients and hormonal preparations users didn't entered study. The patients must avoid from any temporary affecting factors on prolactin serum level in the last 12 hours. Fasting blood was taken in the period of follicular phase and the serum level of prolactin was determined by ELISA method and compared between 2 groups. The data analysis was performed by T-test, Mann Weithney U and Qui ${ }^{2}$ tests in SPSS 19 software.

Results: A total of 57 patients with chronic migraine and 57 patients with episodic migraine with mean age of $33.0 \pm 8.8$ and 32.7 \pm 8.7 years old respectively $(\mathrm{P}=0.712)$ participated in this study. The mean serum level of prolactin was $20.92 \pm 12.14 \mathrm{ng} / \mathrm{dL}(95 \%$ CI: $17.69-24.14)$ and $16.36 \pm 9.34 \mathrm{ng} / \mathrm{dL}(95 \% \mathrm{CI}: 13.88-18.84)$ respectively $(\mathrm{P}=0.036)$. Also with omitting the age effect the difference was significant $(\mathrm{P}=0.022)$. The prevalence of hyperprolactinemia in chronic and episodic migraine was $28.1 \%$ and $12.3 \%(\mathrm{P}$ $=0.036)(\mathrm{OR}=2.8,95 \%$ CI: 7.42 - 1.04).

Conclusion: The prolactin serum level and the prevalence of hyperprolactinemia in chronic migrainous was higher than episodic ones.

Manuscript accepted for publication April 22, 2013

${ }^{a}$ Guilan Road Trauma Research Center, Poursina Hospital, Guilan University of Medical Sciences, Rasht, Iran

${ }^{\mathrm{b}}$ Corresponding author: Roudbary Seyed Ali, Guilan Road Trauma Research Center, Poursina Hospital, Guilan University of Medical Sciences, Rasht, Iran. Email: aliasaberi@yahoo.com

doi: http://dx.doi.org/10.4021/jnr189w
Keywords: Migraine; Chronic migraine; Prolactin; Hyperprolactinemia

\section{Introduction}

Headache is one of the most common complaints among referred patients, so that more than $90 \%$ of men end $95 \%$ of women experience one type of headache during their life. Migraine is one of the most common headaches that is familial and begins during childhood and adulthood with decreasing frequency and severity with increasing age which contains two types of episodic and chronic [1] which characterized by headaches on 15 or more days per month with at least 8 days per month fulfilling International Headache Society (IHS) diagnostic criteria for migraine for at least 3 months in the absence of ongoing medication overuse. Chronic migraine patients usually have a history of episodic migraine, and the evolution from episodic to chronic migraine is gradual. The treatment of chronic migraine is more difficult than episodic and causes significant disability among patients. WHO introduced migraine as one of the most disabling condition [1].

It seems that the cause of chronic migraine is the change in the threshold of pain perception and central sensitization that occurred following frequent migraine attacks and can cause damage to periaqueductal gray matter that it aggravates central sensitization and cause a defective cycle that it's controlling is more difficult [2].

Migraine pathogenesis by dopamine was described by Scutari in 1997 and the signs and symptoms of migraine, it's prodromal and postictal phase were attributed to over activity of dopaminergic system [3]. Considering the inhibitory effect of dopamine on prolactin secretion some investigators have assessed the association of prolactin with migraine as not only its direct role but also as a reflector of dopamine affect on migraine [4-7].

Prolactin is unique because of its controlling by central inhibitory mechanism. Dopamin transmits from hypothalamus to hypophys by its portal vessels, and attaches to dopamine receptor type $2\left(D_{2}\right)$ and inhabits lactotroph cell secre- 


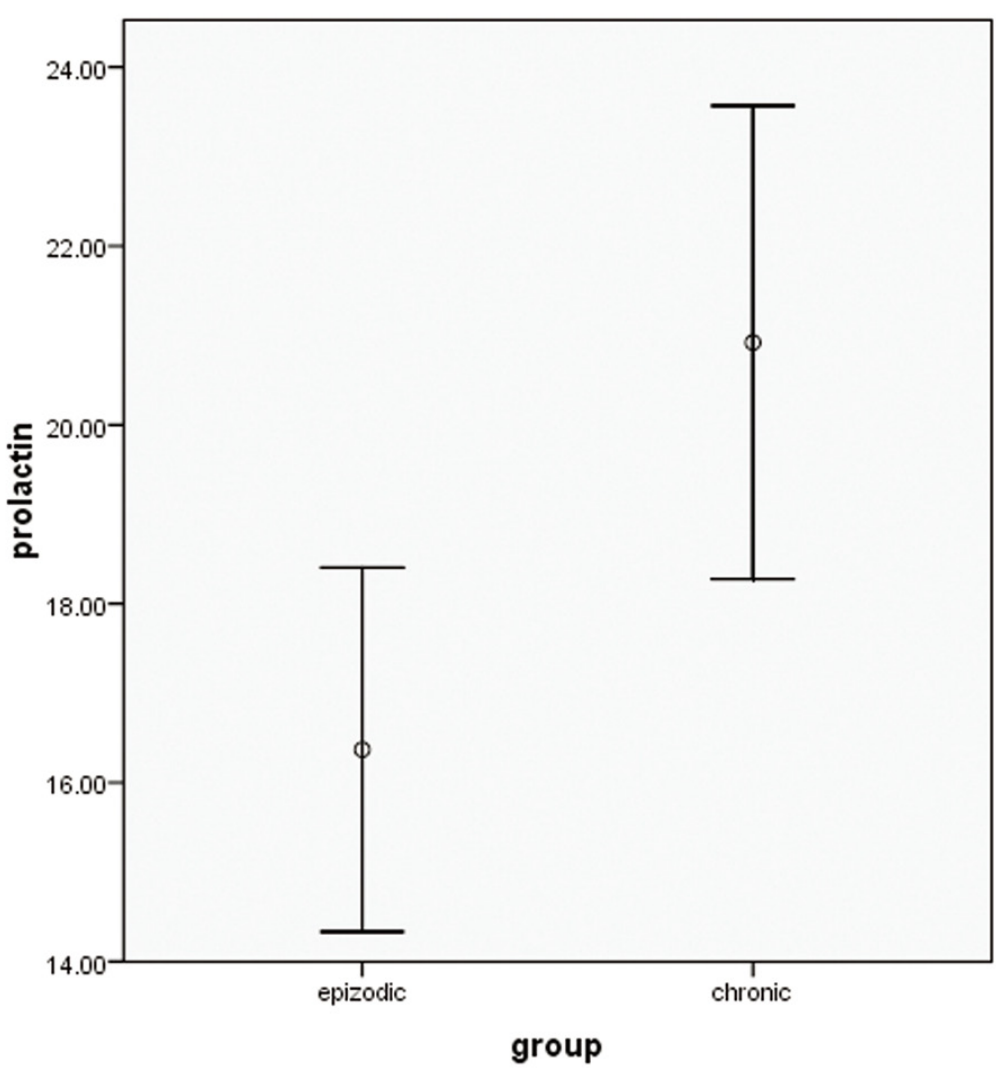

Figure 1. Serum prolactin level of chronic and episodic migrainous patients.

tion. In addition, it inhabits expression of prolactin gene and multiplying of lactrotroph cells [8].

In some studies, it is suggested that hyperprolactinemia among patients with microprolactinoma, can cause migraine type headache without the space occupying effect of tumor [6]. In an Iranian study, the decreasing serum level of prolactin was seen during acute phase of migraine [7]. But it is not clear how much is serum prolactin level interictally and in chronic migraine. In some studies increasing level of prolactin was introduced as a worsening factor for migraine [9] and in the others, its nocturnal peak level was found to be decreased in chronic migraine [10].

In the present study the investigator compared the serum level of prolactin between chronic and episodic migraine patients and the effect of prolactin on chronicity of migraine in order to reach to more advanced clinical trials which change the serum level of prolactin to treat chronic migraine.

\section{Materials and Methods}

In this cross-sectional study that was performed from Jull 2011 till September 2012, the women with chronic migraine and episodic migraine (according to IHS criteria-ICHDII) that were referred to a neurology clinic associated with
Guilin University of Medical Sciences in the north of Iran participated after fulfilling an informed consent. The sample volume was estimated 57 patients in each group of chronic and episodic migraine on the base of a pilot study among 12 chronic and 12 episodic migrainous women with means of serum prolactin level $22.72 \pm 13.05$ and $16.09 \pm 8.2 \mathrm{ng} / \mathrm{dl}$ respectively with test poverty of $90 \%$ and type 1 error $5 \%$. The subjects who involved by menstrual irregularity, anxiety, depression, hypo or hypothyroidism, anemia, polycytemia, epilepsy, and pregnant, lactating, prepuberty and postmenopause patients and hormonal preparations users didn't entered study.

Because of differences of serum prolactin level during menstrual cycle, the blood sampling was performed in one day during follicular phase at $9 \mathrm{am}$, after 8 hours fasting and with considering half life of prolactin as 3.5 hours the patients should avoid from any temporary confounding factors of prolactin serum level, including hard exercise, intercourse, insomnia, stress in the last 12 hours. The blood samples were centrifuged and the serum level of prolactin determined by ELISA. The serum prolactin level more than $25 \mathrm{ng} / \mathrm{dL}$ was considered as hyperprolactinemia. We used Ttest and Mann Whitney U tests according to the normality of data which was determined by Kolmogorov Smirnov (KS) test at first and also Qui test by using SPSS 19. 


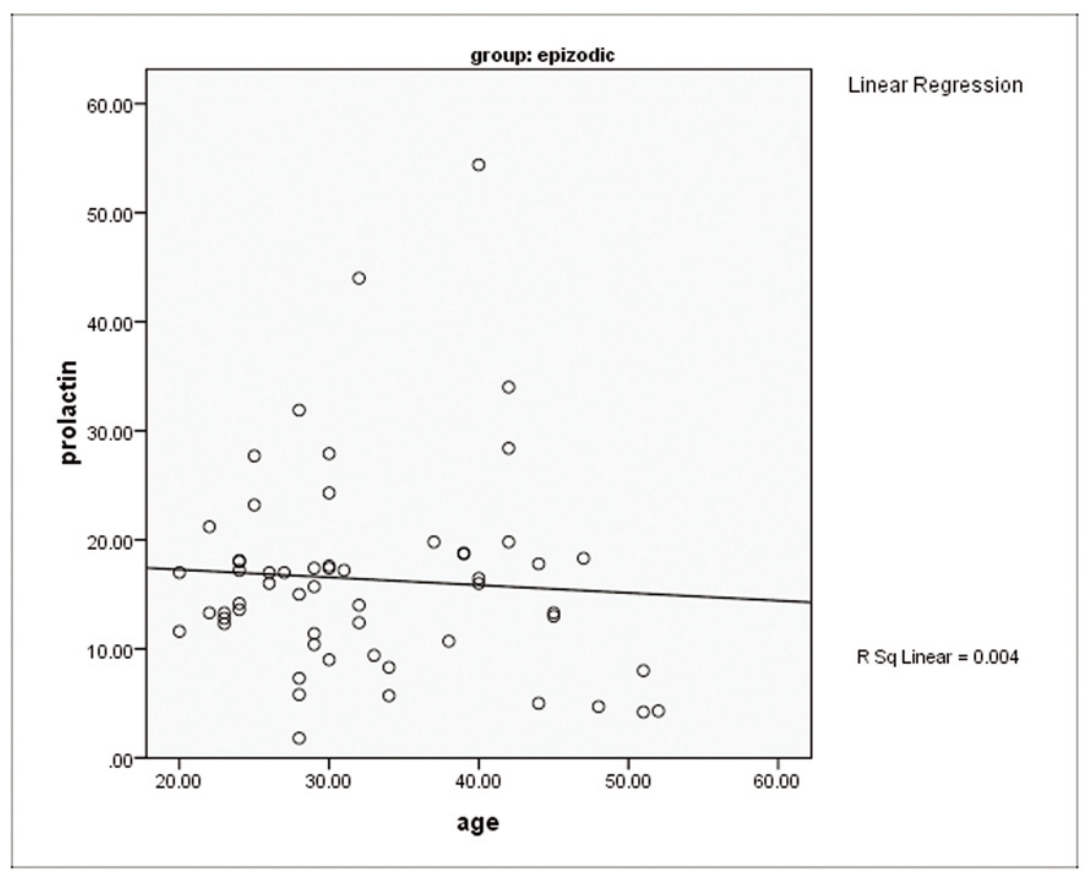

Figure 2. The change of serum prolactin level with increasing age in episodic migrainous patients.

\section{Results}

A total of 114 women containing 57 chronic and 57episodic migrainous patients with mean age of $33.0 \pm 8.8$ and 32.7 \pm 8.7 years old respectively $(\mathrm{P}=0.712)$ participated in this study.

The mean of serum prolactin level among chronic migrainous was determined as $20.22 \pm 12.14 \mathrm{ng} / \mathrm{dL}$ (95\% CI: $17.69-24.14)$ and in episodic migrainous was $16.38 \pm 9.34$ $\mathrm{ng} / \mathrm{dL}(95 \%$ CI: 13.88 - 18.84) that there was significant dif-

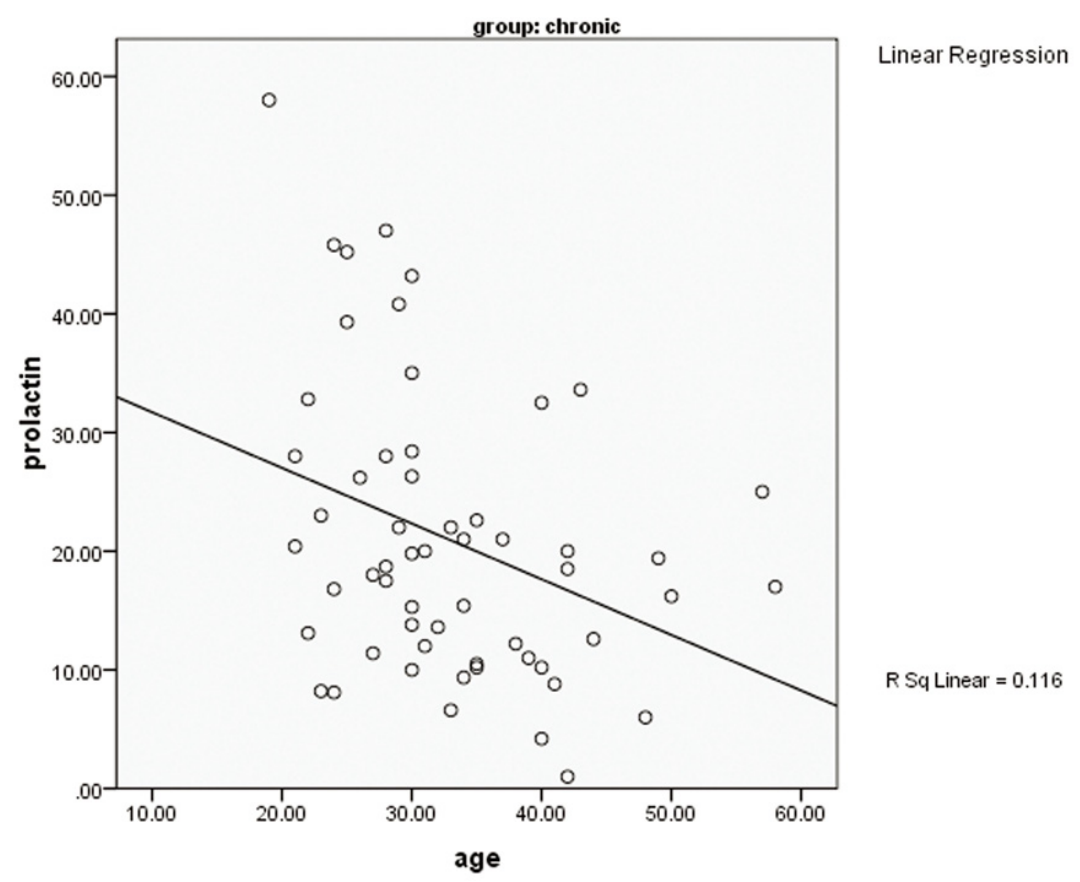

Figure 3. The change of serum prolactin level with increasing age in chronic migrainous patients. 
Table 1. Determination the Effect of Prolactin on Chronic and Episodic Migraine With Omitting the Confounding Effect of Age

\begin{tabular}{|c|c|c|c|c|c|}
\hline & & \multicolumn{2}{|c|}{ Non standardized coefficient } & \multirow{2}{*}{$\begin{array}{l}\text { Standardized coefficient } \\
\beta\end{array}$} & \multirow[t]{2}{*}{ P-value } \\
\hline & & Regression coefficient & Standard error & & \\
\hline \multirow[t]{2}{*}{1} & (constant) & 27.44 & 3.96 & & 0.0000 \\
\hline & age & -0.26 & 0.11 & -0.21 & 0.023 \\
\hline \multirow[t]{3}{*}{2} & (constant) & 20.64 & 4.85 & & 0.0000 \\
\hline & age & -0.27 & 0.11 & -0.21 & 0.019 \\
\hline & group & 4.63 & 1.98 & -0.21 & 0.022 \\
\hline
\end{tabular}

ference between them $(\mathrm{P}=0.036)$ (Fig. 1).

The prolactin level decreases with increasing age in all of migrainous $(\mathrm{P}=0.007)$ and among episodic $(\mathrm{P}=0.539)$ and chronic migrainous patients $(\mathrm{P}=0.007)$ (Fig. 2, 3). With omitting the effect of age also the difference of serum level of prolactin was significant $(\beta=0.21$ and $\mathrm{P}=0.022)$ (Table $1)$.

The prevalence of hyperprolactinemia among episodic and chronic migrainous was estimated as $12.3 \%$ (7 patients) and $28.1 \%$ (16 patients) with $(\mathrm{OR}=2.8,95 \% \mathrm{CI}: 7.42$ 1.04) $(\mathrm{P}=0.036 \%)$.

\section{Discussion}

In the present study in comparison of serum level of prolactin among episodic and chronic migrainous we concluded that it was higher among the latter with means of $20.22 \pm$ $12.14 \mathrm{ng} / \mathrm{dL}$ vs $16.36 \pm 9.34 \mathrm{ng} / \mathrm{dL}$ with the level of significance as 0.036 . According to cut off point of $25 \mathrm{ng} / \mathrm{dL}$ of prolactin level the hyperprolactinemia was found more among chronic migrainous $(28.2 \%$ vs. $12.2 \%$ with $\mathrm{P}$ value $=0.036$ ).

Although with increasing age the prolactin level decreases in both group and totally and with omitting the age effect the difference was significant also.

Although our aim that was determining the effect of high level of prolactin on migraine chronicity irrespective of its reason, but we tried to omit any confounding factor of prolactin level.

In Cavestro et al study in 2006 the increased prolactin level was suggested as a factor for worsening and chronicity of migraine. In this study among 27 chronic migraine patients with a history of episodic migraine, 7 patients had increased prolactin level. The type of their headache didn't change but its severity and frequency had been changed. One of them had a microprolactionma, 6 patients with chronic migraine responded to cabergolin a $\mathrm{D}_{2}$ dopamine receptor agonist that inhibit prolactin secretion. Although this study has a clinical trial adjacent to its description but the sample volume and adjustment of our study was more sufficient [9].

In another study by Press et al the role of hypothalamus in chronic migraine was investigated. The blood sample was taken from 17 chronic migraine patients during 12 hours in every hours and the serum level of melatonin, prolactin, growth hormone and cortisol were measured and decreasing the nocturnal peak level of prolactin among them was seen, so that $53 \%$ of chronic migrainous had peak level of prolactien lower than $25 \mathrm{ng} / \mathrm{mL}$ wherever 2 of 9 subjects in control group had such condition $(\mathrm{P}<0.05)$. In this study the mean of serum prolactin level was lower in chronic migraine (26 vs. $37 \mathrm{ng} / \mathrm{dL}$ ) [10] it is surprising that in the contrary to our study the prolactin level in chronic migraine is lower than episodic one, although the deference wasn't significant $(\mathrm{P}=$ 0.06 ) in Press study. The superiority of this study is the multiplicity of blood sampling in every hours and determining the nocturnal peak level of hormone but their sample volume was very lower than ours.

Considering the high sample volume in our study and omitting the confounding factors effect, we concluded that prolactin serum level is higher in chronic migraine end it may have a role in aggravating migraine. It was seen that prolactin is regulator of sensory neurons especially trigeminal nerves and it is regulated strict by $17-\beta$ estradiol- 3 benzoate $\left(\mathrm{E}_{2}\right)$ that can produce some pain disorders [4]. Also it was seen that microprolactinoma with hyperprolactinemia can produce headache without the effete of space occupying, because its size very small and doesn't compress the pain sensitive structure of skull [6].

So maybe the chronic migraine can be controlled by normalizing the serum level of prolactin, but it is better to design a more widespread clinical trial for assessing this hypothesis. 


\section{Conclusion}

The serum prolactin level and the prevalence of hyperprolactinemia are higher in chronic migraine and it suggests that prolactin can be one of the correspondance to migraine chronicity.

\section{Grant Support}

We were supported by Guilan University of Medical Sciences.

\section{References}

1. Perry J, Mulroy SJ, Renwick SE. The relationship of lower extremity strength and gait parameters in patients with post-polio syndrome. Arch Phys Med Rehabil. 1993;74(2):165-169.

2. Hoffmann S, Tittgemeyer M, von Cramon DY. Cognitive impairment in multiple sclerosis. Curr Opin Neurol. 2007;20(3):275-280.
3. Olesen J, Lipton RB. Headache classification update 2004. Curr Opin Neurol. 2004;17(3):275-282.

4. Diogenes A, Patwardhan AM, Jeske NA, Ruparel NB, Goffin V, Akopian AN, Hargreaves KM. Prolactin modulates TRPV1 in female rat trigeminal sensory neurons. J Neurosci. 2006;26(31):8126-8136.

5. Charbit AR, Akerman S, Goadsby PJ. Dopamine: what's new in migraine? Curr Opin Neurol. 2010;23(3):275-281.

6. Bosco D, Belfiore A, Fava A, De Rose M, Plastino M, Ceccotti C, Mungari P, et al. Relationship between high prolactin levels and migraine attacks in patients with microprolactinoma. J Headache Pain. 2008;9(2):103-107.

7. Masoud SA, Fakharian E. Serum prolactin and migraine. Ann Saudi Med. 2005;25(6):489-491.

8. Ben-Jonathan N, Hnasko R. Dopamine as a prolactin (PRL) inhibitor. Endocr Rev. 2001;22(6):724-763.

9. Cavestro C, Rosatello A, Marino MP, Micca G, Asteggiano $\mathrm{G}$. High prolactin levels as a worsening factor for migraine. J Headache Pain. 2006;7(2):83-89.

10. Peres MF, Sanchez del Rio M, Seabra ML, Tufik S, Abucham J, Cipolla-Neto J, Silberstein SD, et al. Hypothalamic involvement in chronic migraine. J Neurol Neurosurg Psychiatry. 2001;71(6):747-751. 